\title{
PENGARUH TEBAL STYROFOAM CORE TERHADAP BERAT JENIS DAN KEKUATAN TEKAN KOMPOSIT SANDWICH MATRIKPOLYESTER DIPERKUAT SERAT SISAL DAN SERAT POHON PISANG
}

\author{
Sinarep*, Agus Dwi Catur** \\ *,** Dosen Jurusan Teknik Mesin Universitas Mataram \\ Email: sinarepdarek@yahoo.co.id
}

\begin{abstract}
Sandwich composite structure consisting of a core is flanked by two skin. Therefore, the density of the composite sandwich are influenced by core composites material, the more light core the more lightweight composite produced. So also with the composite compressive strength is also very dependent on the core material. In this paper discussed the influence of core thickness on density and compressive strength of composite sandwich.

Sisal fiber or banana tree fibers that have been woven embedded in polyester composites to strengthen the skin. Composite core (Styrofoam) inserted between the two types of laminated composites to reduce weight and increase rigidity. The variation of the thickness of the core is applied in the manufacture of composites. Made of composite density was measured for specific gravity compared to wood or wood products on the market. Compressive strength of composite was characterized to determine the effect of core thickness on the compressive strength of composites.

Research results show that the density of composite decreases with increasing thickness of styrofoam core. Sandwich composite density is much smaller than the specific gravity of wood or wood products on the market.
\end{abstract}

Key words: composite sandwich, core, compressive strength, density.

\section{PENDAHULUAN}

Komposit polimer yang telah diperdagangkan luas saat ini seperti atap rumah, bak air, komponen otomotif dan lainnya dibuat berpenguat dari serat gelas, serat karbon yang merupakan serat sintetis. Serat sintetis tidak ramah lingkungan pasca pakai, serat ini tidak lapuk dan akan tetap sebagai sampah atau limbah pasca pakainya.Serat sintetis juga memerlukan energi yang besar dalam pembuatannya sehingga memerlukan biaya produksi yang lebih tinggi. Sejak lingkungan merupakan isu yang serius, bahan biodegradable merupakan obyek riset yang harus segera dapat diaplikasikan dan menguntungkan secara komersial.

Kini dengan tingginya harga minyak mentah dunia dan kesepakatan mengenai penyelamatan lingkungan maka penggunaan serat alam mulai dikembangkan untuk penggunaan industri tekstil, bangunan, plastik dan otomotif. Serat alam cellulosic sangat potensial untuk digunakan sebagai pengganti serat-serat sintetis yang dijadikan sebagai penguat komposit karena lebih ringan, performa yang tinggi dengan kekuatan yang dapat diterima, mudah di dapat, biaya rendah, dapat mengerakkan ekonomi pedesaan, sumbernya dapat diperbarui, tumbuhan penghasilnya dapat menyerap karbon dioksida dan dapat terurai sehingga ramah lingkungan (Chen,Y.,dkk,2008).

Serat tumbuhan seperti serat nanas, ramie, jute, serat pisang, flax, coir dengan spesies yang berbeda-beda di berbagai belahan dunia umumnya dipakai untuk tambang, tali, sak, jaring ikan, keset, pengisi matras, bantal, tas, barang souvenir dan kover lantai(Saxena, M., dkk., 2000). Juga dilaporkan bahwa serat tumbuhan untuk menggantikan serat sintetis pada komposit polimer mampu mengurangi biaya bahan. Alasan yang lain adalah karena serat alam mempunyai modulus yang baik dan berat jenis yang rendah. Mathur, V.K. (2005).

Serat nanasbali (agave sisalana wiberi) termasuk serat tumbuhan yang moderat pada lingkungan lembab, sifat menyekat panas dan meredam suara. Selain biaya yang rendah dan dapat diperbarui, pembuatan kompositnya memerlukan peralatan yang sedikit, ini memberi peluang pada serat nanassebagai penguat komposit untuk bahan struktural dan karena sifat mekanik yang baik dan ramah lingkungan. Beberapa penelitianmengembangkan produk komposit plastik dengan penguat serat tumbuhan untuk beberapa aplikasi konstruksi seperti bahan atap, plafon, panel-panel, keset, dan bahan bangunan lain dengan biaya yang rendah.

Expandable polystyrene dalam bentuk foam yang lebih dikenal sebagai styrofoam banyak digunakan untuk paking barang elektronik, juga berbagai macam tempat makanan cepat saji, isolator, bantalan furniture, kerajinan tangan. Styrofoammempunyai densitas yang rendah $1,05 \mathrm{gr} / \mathrm{cc}$, kekuatan tarik 0,031 MPa sehingga tidak dapat digunakan sebagai bahan struktural (Meier,1996). Namun memakainya sebagai inti pada komposit 
sandwich dapat menjadikannya sebagai komponen struktural bangunan.

Komposit sandwich berintikan styrofoamtergolong pada structural insulating panels/SIPs. SIPs ditempatkan pada berbagai komponen bangunan seperti dinding, atap, lantai, saluran udara, saluran uap pada bangunan. Penggunaan SIPs mempunyai beberapa keuntungan dibandingkan dengan penggunaan bahan penyekat bangunan konvensional seperti dinding bata, kaca, ataupun kayu, yaitu mempunyai sifat penyekat yang tinggi, bahan bangunan yang ringan, rangka yang kecil, biaya perbaikan yang kecil juga.

Komposit sandwich diproduksi dan dikarakterisasikan, matrik polyester tak jenuh dipadukan dengan serat sisal dan serat pohon pisang sebagai penguat kulit komposit dan styrofoam sebagai inti komposit. Pada tulisan ini diulas mengenai pengaruh ketebalan core terhadap kekuatan tekan komposit.

\section{Bahan dan Metode}

Penelitian diawali dengan pengambilan serat dari tanaman sumber serat daun. Serat sisal diambil dari daun tanaman Nanas Bali (agave sisalana weberi) yang sudah dewasa ditandai dengan warna hijau tua pada daun, serat pohon pisang diambil dari pohon pisang bagian luar yang sudah tua.

Keseragaman serat perlu dijaga dengan mengambil daun yang mempunyai panjang mendekati sama. Daun kemudian digesek dengan pisau tajam agar lapisan palisade tissue tempat klorofil, epidermis dan lapisan cuticula hilang. Daun yang sudah bersih akan tampak serat-seratnya yang berwarna putih kekuningan. Agar seratnya dapat diambil dengan mudah daun direndam kedalam air selama dua hari. Serat dipisahkan dari daging daun dengan menyisir daun menggunakan bambu bercelah secaraberulangulang sampai diperoleh serat yang bersih. Serat kemudian dikeringkan dibawah sinar matahari selama satu hari.

Serat nanas dan serat pohon pisang direndam dalam larutan $4 \% \mathrm{NaOH}$ selama 2 jam didalam wadah terbuat plastik untuk menghilangkan lapisan lilin dan lignin pada serat. Serat kemudian dicuci dalam air mengalir untuk menghilangkan $\mathrm{NaOH}$ yang masih membasahi serat. Pencucian serat kemudian dilakukan pada air ledeng kemudian dikeringkan pada udara panas di dalam oven pada $70^{\circ} \mathrm{C}$ selama 3 jam. Dalam pembuatan kulit komposit susunan serat adalah anyaman tegak lurus.

Pembuatan kulit komposit dilakukan dengan teknik hand lay up atau sering disebut wet lay-up. Langkah awal adalah mengoleskan pengkilap porselin (MAA) dan dikeringkan, ini bertujuan untuk mempermudah pengangkatan spesimen dari cetakan pada saat spesimen sudah kering. Sebelum dicetakan polyester dicampur dengan katalis berupa metil etil keton sebanyak $1 \%$ berat polyester disebut sebagai catalized polyester.

Resin catalized polyester dan serat ditimbang untuk perbandingan penguat matrik sebesar $10 \%$, $20 \%, 30 \%$ volume untuk serat terhadap volume kulit komposit. Sebagian resin yang telah tercampur dituangkan ke dalam cetakan dan diratakan. Serat yang dianyam tegak lurus dimasukkan dalam cetakan, dibenamkan dalam resin kemudian diratakan lagi. Resin sisa dituangkan dan diratakan lagi, kemudian cetakan ditutup dan ditekan dengan menggunakan klem, pengkleman harus dilakukan secara bersamaan agar penekanannya merata, penekanan ini bertujuan untuk mendapatkan ketebalan spesimen yang diinginkan. Setelah itu cetakan yang sudah berisi resin dan serat tersebut didiamkan selama 24 jam, setelah memadat cetakan dibuka dan kulit komposit diangkat dari dalam cetakan dan dipotong sesuai dengan ukuran yang dibutuhkan.

Konstruksi komposit sandwich terdiri dari corestyrofoam dan kulit komposit sendwich yang terdiri dari dua laminat yang mengapitnya. Pada pembuatan komposit sandwich ini antara core dan kulit direkatkan dengan perekat epoxy. Styrofoam yang dipakai mempunyai ketebalan divariasikan masing-masing 20, 30, $40 \mathrm{~mm}$.

Komposit dibiarkan memadat / menyatu (curing) antara kulit dan core didalam ruangan selama 6 jam, untuk menyempurnakan proses pemadatan maka komposit dicuring didalam oven pemanas pada suhu $60^{\circ} \mathrm{C}$ selama 3 jam. Komposit sandwich dikeluarkan dari oven dan setelah dingin dipotong dengan gergaji untuk membuat spesimen uji.

Karakterisasi sifat fisik komposit sandwich didasarkan pada ASTM D792-91 untuk mengukur berat jenis komposit. Komposit sandwich dipotong dengan ukuran $31 \mathrm{~mm} \times 100 \mathrm{~mm} \times$ tebal kemudian ditimbang dengan timbangan digital dengan ketelitian 0,01 gram. Berat jenis komposit adalah berat komposit dibagi dengan volume komposit.

Kekuatan tekan tegak lurus permukaan komposit diuji dengan kecepatan regangan $5 \mathrm{~mm} /$ menit dengan univesal testing machine buatan Hungta Instrumen kapasitas 10 ton. Standar uji tekan yang dipakai adalah ASTM D5456. Ukuran spesimen uji tekan $100 \mathrm{~mm} \times 100 \mathrm{~mm}$ dengan ketebalan sesuai tebal komposit.

\section{Hasil dan Pembahasan Berat Jenis Komposit}

Karakteristik komposit yang diuji adalah salah satunya berat jenis komposit. Berat jenis perlu diukur pada komposit, berat jenis yang kecil memudahkan bahan diangkut dengan biaya bahan bakar yang lebih sedikit. Apabila penggunaan komposit adalah sebagai material konstruksi bangunan 
maka konstrusi mempunyai bobot yang kecil sehingga bila terjadi gempa energi gempa konstruksi kecil.

Pada penelitian ini dicari berat jenis komposit dan dibandingkan dengan berat jenis kayu dan produk kayu. Berat jenis produk kayu yang diambil adalah berat jenis plywood, sedang berat jenis kayu adalah berat jenis kayu yang banyak dipakai yaitu meranti. Berat jenis plywood diambil dari perhitungan-sifat panel standar American Plywood Assosiation(APA). Berat jenis plywood panel tersebut adalah berkisar $564-589 \mathrm{~kg} / \mathrm{m}^{3}$. Sedangkan berat jenis kayu meranti diukur dengan menimbang berat balok kayu meranti dan hasilnya dibagi dengan ukuran balok tersebut.

Dari ketiga spesimen kayu meranti tersebut maka berat jenis rata-rata kayu meranti adalah 621 $\mathrm{kg} / \mathrm{m}^{3}$.

Tabel 1 Berat jenis komposit sandwich

\begin{tabular}{|l|r|r|r|r|r|r|}
\hline \multicolumn{7}{|c|}{ beratjeniskomposit (gram/cc) } \\
\hline jenisserat & \multicolumn{3}{|c|}{ seratbatangPisang } & \multicolumn{3}{c|}{ seratdaun sisal } \\
\hline tebal core & $20 \mathrm{~mm}$ & $30 \mathrm{~mm}$ & $40 \mathrm{~mm}$ & $20 \mathrm{~mm}$ & $30 \mathrm{~mm}$ & $40 \mathrm{~mm}$ \\
\hline $20 \%$ serat & 0.378 & 0.294 & 0.249 & 0.381 & 0.296 & 0.250 \\
\hline $30 \%$ serat & 0.376 & 0.293 & 0.248 & 0.380 & 0.296 & 0.250 \\
\hline $40 \%$ serat & 0.374 & 0.291 & 0.247 & 0.380 & 0.295 & 0.250 \\
\hline
\end{tabular}

Dari table perhitungan tersebut diatas maka berat jenis komposit berkisar antara 0,25 - 0,381 gr/cc atau $250-381 \mathrm{Kg} / \mathrm{m}^{3}$. Terlihat pada tabel bahwa semakin banyak persentase volume serat hanya mengurangi sedikit berat jenis komposit. Demikian juga variasi jenis serat penguat tidak memberikan pengaruh yang banyak pada berat jenis komposit.

Penyusun komposit sandwich ini adalah kulit dan core, keduanya memberi kontribusi terhadap berat jenis komposit. Core berupa styrofoam, memberikan pengaruh yang banyak pada berat jenis komposit. Polyester tak jenuh mempunyai berat jenis 1,1 gram/cc, berat jenis serat nanas $1,08 \mathrm{gr} / \mathrm{cc}$, berat jenis serat pohon pisang 1,03 gr/cc sedangkan berat jenis styrofoam yang dipakai pada penelitian ini adalah 0,1 gr/cc.

Menambahkan styrofoam sebagai core pada komposit sandwich berakibat mengurangi berat jenis komposit secara siknifikan, karena berat jenis core yang ditambahkan lebih rendah daripada kulitnya. Semakin banyak komponen yang berat jenisnya rendah maka semakin rendah berat jenis komposit yang disusunnya. Semakin tebal styrofoam core maka semakin kecil berat jenis kompositnya, ini terlihat pada gambar grafik berikut.

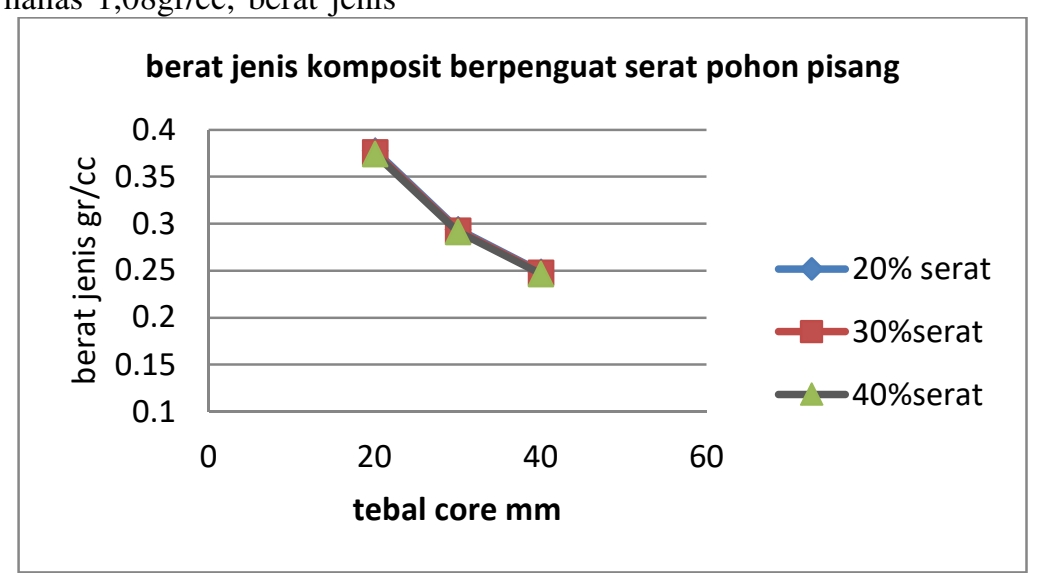

\section{Gambar 2 Grafikberatjeniskomposit sandwich berpenguatseratpohonpisang}

Komposit penelitian ini disiapkan untuk pengganti panel kayu, maka pembanding berat jenisnya juga dilakukan terhadap berat jenis panel kayu atau produk kayu. Nilai berat jenis plywoodberkisar 564 - $589(\mathrm{~kg} / \mathrm{m} 3)$, sedangkan berat jenis kayu meranti $621 \mathrm{~kg} / \mathrm{m}^{3}$, ini jauh lebih besar dari nilai berat jenis komposit hasil penelitian ini yaitu antara $250-381 \mathrm{Kg} / \mathrm{m}^{3}$. Nilai berat jenis panel komposit yang kecil merupakan peran core berupa styrofoam. Berat jenis core yang kecil yaitu $0,1 \mathrm{gr} / \mathrm{cc}$ 
memperkecil berat jenis komposit sandwich secara keseluruhan.

\section{Kekuatan Tekan Komposit Sandwich}

Kekuatan tekan komposit ditentukan oleh gaya maksimal yang dapat ditahan oleh styrofoamcore saat aktuator ditekankan dipermukaan kulit komposit. Gaya tekan dari actuator diteruskan ke styrofoamcore oleh lapisan kulit komposit. Kekuatan tekan komposit sangat tergantung pada kekuatan tekan styrofoamcore, semakin kuat styrofoamcore menahan beban tekan maka semakin tinggi kekuatan tekan komposit.

pengujian tekan yang telah dilakukan didapatkan data kekuatan tekan cenderung tetap seiring dengan semakin besarnya variasi volume serat, dimana perbedaannya tidak terlalu jauh karena pada pengujian tekan, bagian yang mengalami kerusakan pertama kali adalah core karena bagian ini merupakan bagian yang paling rapuh, dimana pada setiap variasi serat memiliki jenis dan bentuk core yang sama sehingga tidak terlalu berpengaruh terhadap perbedaan kekuatan tekan komposit pada setiap variasi serat. Pada proses pengujian, spesimen akan terus di kenai beban sampai spesimen tersebut menjadi rusak karena tidak mampu menahan beban yang di berikan, ini di tandai dengan menyusutnya volume komposit akibat pembebanan tersebut.

Kekuatan tekan komposit sandwich cenderung berkurang dengan bertambah tebal styrofoamcore, walaupun kecenderungannya sangat kecil. Semakin tebal core semakin banyak kemungkinan terjadinya cacat produksi pada Styrofoam. Semakin tebal core semakin banyak pula kemungkinan tidak senternya gaya tekan pada komposit saat core mulai terdeformasi pada pengujian tekan.

Tabel 2 kekuatan tekan komposit sandwich

\begin{tabular}{|c|c|r|r|r|}
\hline \multicolumn{4}{|c|}{ kekuatantekankompositMPa (N/mm2) } \\
\hline & & \multicolumn{3}{|c|}{$\%$ serat } \\
\hline \multirow{2}{*}{ serat } & tebal core mm & $20 \%$ & $30 \%$ & $40 \%$ \\
\hline \multirow{3}{*}{ pisang } & 20 & 1.73 & 1.75 & 1.77 \\
\cline { 2 - 5 } & 30 & 1.59 & 1.6 & 1.62 \\
\cline { 2 - 5 } & 40 & 1.38 & 1.4 & 1.4 \\
\hline \multirow{3}{*}{ sisal } & 20 & 1.74 & 1.75 & 1.79 \\
\cline { 2 - 5 } & 30 & 1.61 & 1.62 & 1.65 \\
\cline { 2 - 5 } & 40 & 1.49 & 1.51 & 1.5 \\
\hline
\end{tabular}

Komposit sandwich dengan tebal Styrofoam core $20 \mathrm{~mm}$ memiliki kekuatan tekan rata-rata tertinggi dibandingkan dengan ketebalan lain yaitu sebesar 1,79 MPa. Selanjutnya kekuatan tekan tertinggi komposit sandwich dengan tebal Styrofoam core $30 \mathrm{~mm}$ dengan nilai rata-rata sebesar $1,65 \mathrm{MPa}$ dan nilai rata-rata kekuatan tekantertinggi pada variasi tebal Styrofoam core $40 \mathrm{~mm}$ sebesar 1,50 MPa. Sedangkan kekuatan tekan komposit secara keseluruhan berkisar antara 1,36 - 1,79 $\mathrm{MPa}$, seperti terlihat di tabel diatas.

\section{Kesimpulan}

1. Berat jenis komposit sandwich dengan Styrofoam core ,kulit komposit dari polyester

\section{DAFTAR PUSTAKA}

1. Acharya, S.K. dan Mishra, S.C., Weathering Behavior of Fly-ash Jute Polymer Composite,Journal of Reinforced Plastics and Composites,2007, vol.26, hal. 1201.

2. Anonim, Composite Material Handbook, Volume 3: Polymer Matrix Composite, material usage, design and analysis, Departemen of defense, USA, 2002. tak jenuh berpenguat serat nanas dan serat pohon pisang lebih kecil disbanding dengan berat jenis kayu ataupun plywood. Berat jenis komposit tersebut berkisar antara 0,25 $0,381 \mathrm{gr} / \mathrm{cc}$ atau $250-381 \mathrm{Kg} / \mathrm{m}^{3}$.

2. Kisaran kekuatan tekan komposit secara keseluruhan berkisar antara 1,36-1,79 MPa, tidak terjadi perbedaan yang mencolok pada nilai tersebut dengan adanya variasi tebal core dan persentase serat.
3. Anonim, Pembanguna PLTU Batubara Harus Memaksimalkan Produksi Dalam Negeri, Portal Nasional RI, http://www.Indonesia.go.id,2008

4. Baker,A.W.,APA Hand Book, Chapter Two:Wood Structural Panels,2005, hal 2.57.

5. Chen,Y., Müller, D.H., Nießen,K., Müssig, J.,Spunlaced Flax/Polypropylene Nonwoven as Auto Interior Material: Mechanical 
Performance, Journal of Industrial Textiles,2008,vol.38,hal.69.

6. Cipta,H., Pengaruh Konsentrasi dan Lama Perendaman Larutan $\mathrm{NaOH}$ pada Permukaan Serat Nanas Bali(agave sisalana) Weberi Terhadap Kekuatan Tariknya, dan Morfologi Permukaannya, Skripsi, 2008, Teknik Mesin, Universitas Mataram.

7. Clemons, C., Sanadi,A.R., Instrumented Impact Testing of Kenaf Fiber Reinforced Polypropylene Composites: Effects of Temperature and CompositionJournal of Reinforced Plastics and Composites,2007,vol.26, hal. 1587.

8. John, K. dan Naidu, S.V, Tensile Properties of Unsaturated Polyester-Based Sisal Fiber-Glass Fiber Hybrid Composites, Journal of Reinforced Plastics and Composites,2004,vol. 23,hal. 1815.

9. Khoatane, M. C., Vorster, O. C., Sadiku, E.R., Hemp Fiber-Reinforced Pentene/Polypropylene Copolymer: The Effect of Fiber Loading on the Mechanical and Thermal Characteristics of the Composites, Journal of Reinforced Plastics and Composites, 2008,vol.27, hal. 1533.

10. Khoo,T.S., Ratnam, M.M., Khalil,H.P.S.A,Wood Filler(WF)-recycled Polypropylene (RPP) Composite Pallet: Study of Static Deformation using FEA and Shadow Moire, Journal of Reinforced Plastics and Composites,2008, vol.27, hal. 1733. 